\section{Novas perspectivas sobre a República no Brasil}

VISCARDI, Cláudia Maria Riberio \& ALENCAR, José Almino (orgs.). A República revisitada: construção e consolidação do projeto republicano brasileiro. Porto Alegre, EDIPUCRS, 2016. 341 páginas.

\section{Jefferson José Queler}

Os primórdios do regime republicano no Brasil recebem importante contribuição com esta coletânea. Publicada recentemente em formato e-book, com organização de Cláudia Maria Ribeiro Viscardi e José Almino Alencar, a obra reúne oito capítulos dedicados à revisão de ideias e práticas políticas relacionadas com o período da chamada Primeira República (1889-1930). ${ }^{1}$ Em linhas gerais, os autores, com formação em história ou ciências sociais, procuram rever teses bastante difundidas sobre um período cristalizado na historiografia como supostamente despido de efetiva representação política. De maneira instigante, ao problematizar essa linha interpretativa, tais estudos lançam novas luzes sobre debates de ideias, disputas políticas e institucionalização partidária naqueles anos.

A maioria dos autores apresentou e discutiu as referidas pesquisas na Fundação Casa de Rui Barbosa entre 2010 e 2012. Outros, apesar de não terem feito o mesmo, foram incluídos no livro por já terem desenvolvido trabalhos relevantes sobre o período. Uma tendência presente em grande parte da coletânea é a de seguir e aprofundar a corrente historiográfica interessada em reavaliar o período tradicionalmente conhecido como "República Velha”. ${ }^{2}$ Igualmente, os autores, de forma geral, alinham-se às críticas ao pensamento autoritário brasileiro, como o de Oliveira Vianna, que considerava a sociedade brasileira amorfa e inorgânica. Nessa vertente intelectual, as eleiçóes, os parlamentos, os partidos políticos e os variados tipos de associativismo são normalmente qualificados como ineptos e/ou desnecessários. E, por isso, tais instituiçôes e práticas são por ela diminuídas ou apagadas (Abreu e Gomes, 2009, p. 3). De maneira distinta, os participantes da obra em questão, ao colocar os sujeitos na história, seguem trilha de grupo de historiadores que reconhece certa dinâmica e efetividade das instituiçóes representativas daquele período. Eles afirmam que os processos eleitorais ao menos propiciavam uma circulaçáo das elites no poder e que as camadas populares desenvolviam significativo aprendizado político (Idem, p. 7). Como indica Ângela de Castro Gomes, no prefácio do livro, são muito naturalizadas fórmulas explicativas sobre o período, como a política do café com leite, o domínio do clientelismo, as fraudes eleitorais, elementos que indicariam a ausência de representação e participação políticas "verdadeiras".

O livro é bastante heterogêneo no que diz respeito aos capítulos. Nele, escrevem desde intelectuais veteranos até jovens pesquisadores, com as mais diversas perspectivas teórico-metodológicas e estilos de escrita distintos. Cabe ressaltar que outras versóes dos textos já foram publicadas em importantes revistas acadêmicas. Na primeira parte, a obra conta com uma bela análise de Christian Edward Cyril Lynch sobre discursos parlamentares proferidos durante a primeira Assembleia Constituinte republicana. Em suas conclusóes, tanto liberais como conservadores partilhavam uma concepção elitista de representação política. Em seguida, Angela Alonso, por meio principalmente de livros publicados no período, traça as principais linhas de debate entre republicanos e monarquistas. Estes, segundo ela, apesar de derrotados politicamente com a queda da monarquia, foram capazes de produzir ampla representação simbólica destinada a combater o regime republicano e seus adeptos. Cláudia $\mathrm{M}$. R. Viscardi e Vitor F. Figueiredo debruçam-se sobre discursos e práticas de Campos Sales. Em suas análises, a "política dos estados" e seus mecanismos para barrar a representação política não aparecem tão eficientes como tradicionalmente se supóe. José Almino de Alencar, por sua vez, disponibiliza documentação inédita ao reproduzir amplos trechos de telegramas trocados entre o Barão do Rio Branco e Rui Barbosa, à época em que este fora delegado do país na Segunda Conferência da Paz em Haia.

$\mathrm{Na}$ segunda parte da coletânea, Paolo Ricci e Jaqueline Porto Zulini investigam as contestaçóes apresentadas pelos candidatos derrotados nas eleiçóes para a Câmara dos Deputados. A despeito das conhecidas coaçóes e violências, os autores indicam que havia considerável competitividade nas eleiçôes 
daquele período. Em seu texto, Américo Freire analisa a atuação de três políticos ligados à cidade do Rio de Janeiro: Lauro Sodré, Augusto de Vasconcelos e Irineu Machado. Tais personagens, segundo ele, oscilavam entre a política clientelista e o fortalecimento da estrutura partidária. De forma semelhante, Surama Conde Sá Pinto problematiza a ideia de um Rio de Janeiro (então capital federal) neutralizado, sem autonomia, institucionalmente débil. Em sua opiniāo, havia atividades partidárias significativas naquela cidade, com a organização e a atuação de diversas legendas. Enfim, Andréa Casa Nova Maia e Pedro Krause Ribeiro lidam com uma série de ilustraçóes sobre a antiga capital federal. Os caricaturistas selecionados, sustentam, não eram meros críticos do poder, pois, em determinadas circunstâncias, apoiavam regimes e certos grupos políticos.

Alguns eixos de discussão da coletânea poderiam ser discutidos mais detalhadamente. Christian E. C Lynch problematiza, de maneira instigante, a interpretação dos vencedores do processo histórico em 1930. Estes, segundo o autor, corroboraram as posiçóes de Rui Barbosa de que o projeto republicano originário teria tido um propósito efetivamente liberal-democrático. Segundo essa interpretação, tal intento teria sido baldado pela interpretação de políticos representantes da elite conservadora, como Campos Sales e Pinheiro Machado. O fato de a Constituição ter ficado presa a interpretaçóes conservadoras, desde pelo menos a Revolta da Armada, com as subsequentes concessóes de estados de sítio e a anulação de liberdades individuais, reforçou tal visão. Em contraponto, Lynch, baseando-se nas falas de parlamentares durante a primeira Assembleia Constituinte republicana, destaca que tanto liberais como conservadores concordavam que a liberdade estava acima da igualdade. A questão do liberalismo, portanto, sobrepunha-se à democracia. Essa visão, como demonstra o autor, teve um papel decisivo na concepção de uma ideia aristocrática de governo, destinada a barrar a ampliação do eleitorado. Essas conclusões, a meu ver, são bastante acertadas ao oferecerem novos elementos empíricos para se pensar o já bastante documentado caráter autoritário tanto do pensamento como das práticas liberais (Losurdo, 2006; Franco, 1993). Entretanto, outros artigos do livro apontam como, a despeito de tais concepçóes e atos restritivos, houve certo espaço para participação política e disputas eleitorais.

Angela Alonso, por sua vez, fundamenta bem como grupos sociais vencidos pela Proclamação da República, os monarquistas, foram bem-sucedidos em fazer prevalecer suas representações simbólicas nas lutas pelo poder. Em oposição aos republicanos, considerados parvenus interessados tão somente em lucros, procuraram construir a imagem idealizada de uma sociedade imperial fundada em valores aristocráticos, como a honra. Assim, o presente se lhes afigurava como um momento de decadência e o futuro, como catastrófico. Em relação ao sucesso dos monarquistas em legar tais concepçóes para a posteridade, poderíamos lembrar a avidez com que o pensamento autoritário se apropriou delas. Oliveira Vianna, por exemplo, em sua obra $O$ ocaso do Império (1925), sugeriu que a monarquia era mais afeita àquilo que considerava ser a sociedade real: uma forma de governo bastante centralizada, em oposição às descentralizadas e supostamente ineficazes instituiçóes representativas republicanas.

Em se tratando ainda do sucesso de alguns sujeitos em estabelecer suas versóes sobre os acontecimentos, o capítulo de Cláudia M. R. Viscardi e Vitor F. Figueiredo é muito esclarecedor. Segundo os autores, o trabalho memorialístico de Campos Sales deixou marcas profundas na historiografia. As afirmaçôes do político, imbricadas nas lutas políticas do momento em que escrevia, acabaram por se cristalizar como mecanismos explicativos para a Primeira República. Em sua perspectiva memorialística, a "política dos estados" trouxe "estabilidade" para o cenário político daqueles anos por ter supostamente suprimido as disputas partidárias no centro do poder. Contudo, Figueiredo e Viscardi investigam, empiricamente, como a "política dos estados" foi implementada em seus primeiros anos. ${ }^{3} \mathrm{O}$ foco de suas análises recai sobre os efeitos das mudanças regimentais que buscaram alterar o processo de verificação de poderes na Câmara Federal durante o governo de Sales.

Os dados das eleiçóes legislativas de 1900, por exemplo, sugerem que mais da metade das elites políticas não conseguiram barrar as oposiçóes no interior de seus estados. Essa inferência é tecida com 
base nos diplomas apresentados por candidatos teoricamente aptos a exercer cargos legislativos federais em função de expressivas votaçóes. Como o número era bastante elevado, acima do permitido pela lei, os autores chamam a atenção para a possibilidade de que havia considerável grau de cisão entre as elites, bem como disputas candentes entre suas facçóes pela representação parlamentar. Em suma, a "política dos estados" não fora capaz de barrar completamente dissidências nas etapas da candidatura, da eleição e no momento da concessão dos diplomas, ainda que tenha sido planejada para tanto. Tal interpretação, a meu ver, é muito instigante ao indicar que as disputas políticas do período nem sempre eram meras formalidades. Por vezes, interesses diversos podiam driblar as mais variadas barreiras e se fazer representar no Parlamento.

Seguindo trilha parecida, Paolo Ricci e Jaqueline P. Zulini, de modo inovador, sustentam que as práticas de intimidação física e corrupção então vigentes nem sempre triunfavam sobre os resultados das urnas. Trabalhando com fontes de fácil acesso, porém nunca exploradas, os autores analisam sobretudo as acusaçôes formais de irregularidade eleitoral disponíveis nos Anais do Parlamento. Ambos contribuem bastante ao levantarem novas questóes com base nesse material. Afinal, os estudiosos do período costumavam se ater aos embates entre as elites pelo poder sem levar em conta como os atores políticos buscavam evitar a incerteza eleitoral. No texto, por outro lado, tal indefinição, nos momentos dos pleitos, fica clara em razão de a imprensa ter sido ativa na mobilização do eleitorado, bem como pelo fato de os candidatos terem feito intensas campanhas, seja com visitas a municípios, campanhas nas ruas, ou até mesmo interpelando o eleitor de porta em porta. No que diz respeito aos votos, o próprio fato de que estes eram com frequência negociados ou comprados, atesta o quanto seus destinos não eram certos no momento da votação.

Entretanto, alguns dos argumentos de Ricci e Zulini poderiam ser discutidos com maior profundidade. No que diz respeito ainda à ocorrência de competição eleitoral, por exemplo, eles asseveram que grande parte das disputas entre as elites se dava pelo controle da máquina administrativo-eleitoral em suas múltiplas instâncias: o alistamento e a quali- ficação dos eleitores, a composição das mesas eleitorais e a diplomação dos eleitos pelas Juntas Apuradoras. Nesse sentido, mesmo os entraves burocráticos para eventuais opositores e minorias nos momentos de definição do corpo eleitoral, bem como as famigeradas atas forjadas, não teriam invalidado a competição acirrada pelo controle dos referidos fóruns. Em outras palavras, em um sistema político amplamente considerado despido de competitividade, é possível identificar uma série de embates e disputas nas próprias instâncias em que se processavam, com frequência, as conhecidas fraudes.

Tal argumento é bastante original e convincente. Revela, ademais, lutas políticas bastante complexas, centradas não apenas em torno de princípios abstratos, de partidos e do voto, mas também ao redor de disputas por cargos burocráticos. Porém, a interpretação de Ricci e Zulini é problemática quando naturaliza os fins dos postulantes às referidas posiçóes, sob o pretexto de compreender essas práticas nos termos de sua própria época, em uma tentativa de evitar o anacronismo. Ora, tais fraudes não foram criticadas apenas por historiadores, cientistas sociais e memorialistas, mas também por uma série de grupos atuantes naquele período. É o que, a meu ver, demonstra o capítulo escrito por Surama Conde Sá Pinto ao evidenciar que vários jornais cariocas condenaram veementemente a ocorrência dessas práticas fraudulentas. Nesse sentido, as disputas pelos cargos são efetivamente indícios de atividade política, mas seus objetivos, muitas vezes, visavam paradoxalmente à sua anulação.

Uma outra questão que poderia ser discutida com mais rigor é o emprego do termo oligarquia pela maioria dos autores da coletânea, pois em nenhum momento o conceito é definido ou problematizado. Etimologicamente, a noção significa "governo de poucos", porém, emerge no pensamento político grego, por vezes, com o sentido de "governo dos ricos". Em suas formulaçóes iniciais, o termo carrega um sentido marcadamente negativo. Com frequência, diferentemente de democracia e monarquia, oligarquia não designa uma instituição específica. Antes, seus usos restringem-se a chamar a atenção para o fato de que o poder está sob o controle de um grupo diminuto de pessoas. Nesta acepção, tais indivíduos estariam ligados entre si 
por vínculos de sangue, de interesse ou outros. Beneficiários de privilégios, eles fariam de tudo para preservá-los (Bobbio, 1986). Em se tratando do livro em questão, os autores não levam em conta como a noção de oligarquia fora utilizada nas lutas políticas do período, bem como pelos vencedores do processo histórico depois de outubro de 1930.

Conforme já demonstrado pela historiografia crítica da história dos vencedores, ao longo da Primeira República os oponentes do sistema ou os indivíduos que apenas pretendiam tomar parte dele sem modificá-lo taxavam todo grupo no poder de "oligarquia" ou de "oligarquias estaduais", com claro sentido desabonador. Na ótica dos vencedores, por sua vez, a "Revolução de 30" encerrara uma etapa corrompida da história e iniciara outra despida dos vícios anteriores. Esta ruptura, traçada pela memória e história oficiais, foi amplamente incorporada pelas ciências sociais dos anos de 1960. De um lado, estabelecia-se um Estado oligárquico, liberal e federativo, baseado em uma economia agrícola de exportação; de outro, concebia-se um Estado autoritário e centralizado, orientado cada vez mais para a indústria (Borges, 1992, pp. 140141). A força desse esquematismo parece perdurar em diversos momentos da coletânea, uma vez que seus autores não lidam criticamente com o conceito de oligarquia, bastante presente nas lutas políticas e na memória do período estudado.

Contudo, é importante frisar que o emprego do conceito de oligarquia como instrumento analítico é aceitável para o período em questão, mas requer a distinção de algumas nuances. No âmbito do pensamento político, o referido termo, especialmente a partir da obra de Maurice Duverger, vem ganhando crescente valor descritivo na definição da estrutura do poder do Estado moderno. Contudo, é preciso diferenciar alguns tipos de oligarquia à frente de sistemas políticos. Existem aquelas que buscam sua legitimidade no voto popular, ao menos formalmente livre; e existem aquelas que fazem o mesmo através do voto dirigido, da tradição, da força carismática dos chefes e até mesmo do terror. No primeiro caso, o grupo reconhece a oposição legal e assegura, no interior de determinados limites, a liberdade de expressão; no segundo, a elite não admite nenhum desses elementos, tratando de persegui-los onde quer que apareçam (Bobbio, 1986). No que tange à historiografia tradicional sobre a Primeira República, os analistas procuraram demonstrar a existência e o domínio do segundo tipo de oligarquia, elemento ainda importante para se compreender o período. Entretanto, o livro em questão chama a atenção para a presença de ambas as tipologias entre os grupos politicamente dominantes.

Desde que essas ressalvas sejam levadas em consideração, a coletânea organizada por Cláudia M. R. Viscardi e José Almino Alencar, deve se afirmar como importante referência para historiadores, cientistas sociais e todos aqueles interessados na história política brasileira. Pensada e escrita num momento em que as instituiçôes democráticas do país pareciam firmes e consolidadas, sua ênfase recai nas diversas formas de participação política de nossa sociedade nos primórdios do regime republicano; publicada em circunstâncias adversas para a democracia, contudo, suas pistas sobre a participação política popular ao longo daquele período poderiam ser repensadas diante dos eficazes mecanismos erigidos pelas elites brasileiras para contê-la. Nesse sentido, o capítulo escrito por Christian Edward Cyril Lynch ganha ainda mais relevância no contexto atual. A concepção aristocrática e elitista de participação política, presente nas discussóes de nossa primeira Assembleia Constituinte Republicana, ainda parece fincar raízes profundas em nosso presente. E as interpretaçóes autoritárias de nossas elites em relação à nossa Constituição ainda são capazes de barrar a expansão significativa das escolhas do eleitorado.

\section{Notas}

1 A denominação Primeira República foi cunhada por Edgar Carone nos anos de 1970, tomando como base a periodização da história francesa (Borges, 1992, p. 140)

2 Conforme demonstrado pela historiografia há algumas décadas, este termo foi cunhado pelos vencedores do processo histórico em 1930. Em esforço de construção de uma memória histórica, intimamente associada às lutas pelo poder, tais sujeitos estabeleceram a "Revolução de 30" como fato histórico: não apenas para apagar encaminhamentos revolucionários entre os vencidos, como também para decretar um novo co- 
meço, supostamente despido das fraudes e das corrupçôes generalizadas presentes em anos anteriores. Ver Decca (2004) e Vesentini (1997).

3 Com isso, ambos retomam a metodologia de importante trabalho de Viscardi. Ao analisar a efetivaçáo da "política do café com leite", a autora demonstrou como a aliança entre Minas Gerais e Sáo Paulo, diferentemente das interpretaçóes historiográficas tradicionais, fora repleta de conflitos e cisóes. Isso significa, pois, que o pacto estruturado em 1898 não anulou o grau de incerteza do sistema político. Ver Viscardi (2001, p. 33).

\section{Bibliografia}

ABREU, Martha \& GOMES, Angela de Castro. (2009), "A nova 'Velha' República: um pouco de história e historiografia”. Revista Tempo-UFF, 19 (35): 1-14.

BORGES, Vavy Pacheco. (1992), Tenentismo e revolução brasileira. $1^{a}$ edição. São Paulo, Brasiliense.

BOBBIO, Norberto. (1986), "Verbete oligarquia", in N. Bobbio e G. P. Matteucci (orgs.), Dicionário de política, 2. ed. Brasília, Editora da UnB.

DECCA, Edgar de. (2004), 1930, O silêncio dos vencidos: memória, história e revolução. 6. ed. São Paulo, Brasiliense.

FRANCO, Maria Sylvia de Carvalho. (1993), "All the world was America”. Revista USP, 17: 30-53.

LOSURDO, Domenico. (2006), Contra-história do liberalismo. $1^{\text {a }}$ edição. Aparecida, Ideias \& Letras.

VESENTINI, Carlos A. (1997), A teia do fato: uma proposta de estudo sobre a memória histórica. $1^{\text {a }}$ edição. São Paulo, Hucitec.

VISCARDI, Cláudia Maria Ribeiro. (2001), O teatro das oligarquias: uma revisáo da política do café com leite. $1^{a}$ edição. Belo Horizonte, C/ Arte.

\section{JEFFERSON JOSÉ QUELER é professor adjunto em história da Universidade Federal de Ouro Preto (UFOP), campus Mariana. E-mail: jeffqueler@hotmail.com.}

DOI: $10.17666 / 339602 / 2018$ 